\title{
Sexual Violence in Indonesia and Malaysia: A Comparative Study
}

\section{Kuswardani}

Fakultas Hukum Universitas Muhammadiyah Surakarta. E-mail: kus283@ums.ac.id

\begin{tabular}{l} 
ARTICLE INFO \\
\hline Keywords: \\
Indonesian Penal Code, \\
Malaysian Penal Code, \\
Rape, Sexual Violence. \\
How to cite: \\
Kuswardani. Sexual \\
Violance in Indonesia and \\
Malaysia: A Comparative \\
Study. MEDIA HUKUM, \\
+62 274 387656 (Ext. 220) \\
Article History \\
Received: 13/07/2018 \\
Reviewed: 09/05/2019 \\
Revised: \\
Accepted: 25/06/2019
\end{tabular}

\begin{abstract}
Sexual violence (rape) especially committed by boyfriend has been growing rapidly these days. However, the Penal Code cannot be dealt with this issue. In such a case, the sexual intercourse is usually conducted without violence or under threat of violence, but rather based on consent (love). Penal reform should address this issue to accord with the current global development. This paper describes the comparison between the Indonesian Penal Code and the Malaysian Penal Code in governing rape. The result shows that the formulation of rape in the Malaysian Penal Code is broader than its Indonesian counterpart. Under the Malaysian Penal Code, rape is punishable whether it is conducted with or without consent. It seems that the penal reform in Indonesia should adopt the Malaysian approach in order to provide better protection for women from sexual violence. This is also in line with the Beijing Declaration 1993 and the development of the issues in other countries.
\end{abstract}

DOI: 10.18196/jmh.20190122

Copyright (C) 2019 MEDIA HUKUM. All rights reserved.

\section{Pendahuluan}

Masyarakat secara umum mempersepsi kejahatan sebagai suatu perbuatan yang melanggar hukum (undang-undang). Persepsi yang demikian ini sesuai dengan asas legalitas (principle of legality) yang menyatakan "tidak ada kejahatan, tidak ada hukuman tanpa hukum pidana (nullum crimen nulla poena sine praevia lege). ${ }^{1}$ Asas ini dapat dilihat dalam ketentuan Pasal 1 Ayat (1) Kitab Undang-undang Hukum Pidana (KUHP) sebagai berikut: "Tiada suatu perbuatan dapat dipidana kecuali atas kekuatan aturan pidana dalam perundang-undangan yang telah ada sebelum perbuatan itu dilakukan."

Dengan demikian dapat dikatakan bahwa suatu perbuatan bisa disebut sebagai sebuah kejahatan apabila perbuatan itu telah diatur dalam undang-undang pidana.

\footnotetext{
${ }^{1}$ Lamintang, P.A.F. (2013). Dasar-dasar Hukum Pidana Indonesia. Bandung: Citra Adtiya Bakti, p.132.
} 
Bentuk-bentuk kejahatan berkembang sesuai dengan perkembangan masyarakat. Perkembangan ilmu pengetahuan dan teknologi telah memunculkan kejahatankejahatan baru. Disamping itu, konsep kejahatan bisa berkembang karena adanya suatu gerakan sosial tertentu, seperti gerakan yang memperjuangkan kebebasan dan kesetaraan hak-hak perempuan. Gerakan ini telah berhasil memposisikan pelanggaran terhadap hak-hak perempuan sebagai sebuah kejahatan.

Dalam deklarasi Beijing 20 Desember 1993 yaitu Declaration on the Elimination of Violence against Women, kejahatan terhadap hak-hak perempuan atau yang disebut dengan istilah kekerasan terhadap perempuan (violence against women) didefinisikan sebagai berikut: "Violence against women means any act of gender-based violence that results in, or is likely to result in, physical, sexual or psychological harm or suffering to women, including threats of such acts, coercion or arbitrary deprivation of liberty, whether occurring in public or in private life."

Berdasarkan konsep tersebut, maka kejahatan/kekerasan terhadap perempuan bercirikan: (1) perbuatan ditujukan kepada perempuan, sehingga korbannya perempuan; (2) menyerang hak-hak perempuan; dan (3) menimbulkan kerugian baik itu kerugian fisik, psikis dan/atau seksual.

Dalam KUHP, kejahatan/kekerasan terhadap perempuan tidak diatur dalam bab tersendiri, melainkan menjadi bagian Bab XIV tentang Kejahatan terhadap Kesusilaan yang ada di dalam buku II KUHP tentang Kejahatan. Pengaturan tentang kejahatan terhadap perempuan berkembang seiring dengan disahkannya beberapa undangundang pidana di luar KUHP. Terkait kejahatan/kekerasan terhadap perempuan, telah disahkan Undang-undang Nomor 23 Tahun 2004 tentang Penghapusan Kekerasan dalam Rumah Tangga (UU PKDRT). Namun demikian, pengaturan tentang kejahatan terhadap perempuan dalam bentuk perkosaan hingga saat ini masih belum ada perubahan. Pengaturan tentang perkosaan masih merujuk pada KUHP, kecuali yang terjadi dalam lingkup rumah tangga. Khusus untuk perkosaan dalam rumah tangga, pengaturannya ada di dalam UU PKDRT dan undang-undang lainnya. ${ }^{2}$

Realitas tentang kekerasan seksual terhadap perempuan (perkosaan) cukup memprihatinkan. Merujuk pada data yang dikeluarkan oleh Komisi Nasional Perempuan (KOMNAS Perempuan) tahun 2017, kekerasan seksual yang dilakukan oleh pacar menempati peringkat pertama yaitu sebanyak 2.017 kasus. ${ }^{3}$ Meskipun belum menunjukkan jumlah kasus yang sebenarnya (karena fenomena gunung es), data tersebut memberikan gambaran bahwa kasus kekerasan seksual terhadap

\footnotetext{
${ }^{2}$ Konsep kekerasaan seksual dalam lingkup rumah tangga itu dijelaskan dalam Pasal 8 dari UU No. 23 Th. 2004. Sanksi pidananya diatur dalam Pasal 46, 47 dan 48. Ketentuan tentang perkosaan juga terdapat di dalam UU No. 23 Th. 2002 tentang Perlindungan Anak yang telah dirubah dengan UU No. 35 Th. 2014 tentang Perubahan UU No. 23 Th. 2002 tentang Perlindungan Anak. Tahun 2016 mengalami perubahan kedua dengan UU No. 17 Th. 2016 tentang Penetapan Peraturan Pemerintah Pengganti Undang-undang No. 17 Th. 2016 tentang Perubahan Kedua atas Undang-undang No. 23 Th. 2002 tentang Perlindungan Anak. Perbuatan perkosaan dengan korban anak diatur dalam Pasal 76 D UU No. 35 Th. 2014, sedangkan sanksi pidana dari perbuatan tersebut lebih diperberat setelah ada perubahan kedua UU Perlindungan Anak, yaitu diatur dalam Pasal 81 UU No.17 Th. 2016.

${ }^{3}$ KOMNAS Perempuan. (2017). Catatan Tahunan (CATAHU) 2017, online from https://www.komnasperempuan.go.id/file/pdf file/2017\%20Siaran\%20Pers/Lembar\%20Fakta\%20Cata hu\%202017.pdf. [Accessed May 10, 2017].
} 
perempuan cukup tinggi. Oleh karena itu hukum pidana sebagai salah satu sarana penanggulangan kejahatan masih diperlukan, disamping sarana pencegahan lain di luar hukum pidana. Penanggulangan kejahatan dengan hukum pidana dilakukan dengan cara kriminalisasi terhadap perbuatan-perbuatan yang dibenci masyarakat atau berbahaya. Hal ini sebagaimana diungkapkan oleh Philip Petit dalam R.A. Duff et.al, bahwa kriminalisasi merupakan bentuk peraturan pencegahan yang menghalangi tindakan ofensif (one alternative to criminalization would be a form of preventive regulation that screen out offensive act). ${ }^{4}$

Pembaharuan KUHP yang saat ini sedang dilakukan seharusnya memperhatikan hal tersebut, karena kejahatan secara umum maupun khusus kejahatan terhadap perempuan telah mengalami perkembangan, terutama dalam perumusan perbuatan yang disebut dengan kekerasan seksual berikut sanksi pidananya. Oleh karena itu, dalam pembaharuan hukum pidana diperlukan kajian perbandingan (comparative study). Sebagaimana dikatakan Mien Rukmini, dalam pembaharuan hukum pidana diperlukan kajian komparatif dengan perkembangan dan ide-ide mutakhir, karena adanya kesepakatan global. ${ }^{5}$ Sehubungan dengan itu, makalah ini berupaya memaparkan hasil penelitian tentang pengaturan kejahatan perkosaan dalam KUHP Malaysia sebagai perbandingan. Pemilihan KUHP Malaysia sebagai obyek kajian perbandingan, didasarkan pada dua alasan pokok, yaitu faktor geografis dan faktor kesamaan asas hukum.

Terkait alasan pertama, Malaysia dipilih karena memiliki kedekatan geografis dengan Indonesia. Malaysia adalah salah satu negara tetangga yang berbatasan langsung dengan Indonesia. Terkait alasan kedua, asas-asas hukum pidana yang berlaku di Malaysia sama dengan yang berlaku di Indonesia. Asas-asas hukum dimaksud merupakan asas fundamental dalam hukum pidana. Asas tersebut adalah: (a) asas terkait dasar patut dipidananya perbuatan, yaitu bahwa perbuatan seseorang dihukum atas dasar kekuatan undang-undang; (b) asas hapusnya kewenangan menuntut, bahwa orang atau seseorang tidak boleh dituntut dua kali dalam perkara yang sama dan dalam hal putusannya telah mempunyai kekuatan hukum tetap. ${ }^{6}$

Meskipun ke dua negara menganut sistem hukum yang berbeda (Malaysia mengikuti sistem hukum Anglo Saxon, sedangkan Indonesia mengikuti Civil Law System), akan tetapi hal itu tidak menjadi isu. Di era globalisasi, pemisahan yang demikian tidak begitu ekstrim karena adanya arus komunikasi-informasi yang cukup pesat, yang

\footnotetext{
${ }^{4}$ Pettit, P. "Criminalization in Republican Theory “. On R.A. Duff, et al (ed) (2014). Criminalization:The Political Morality of the Criminal Law. USA: Oxford University Press, p. 140.

5 Rukmini. M. "Pembaharuan Hukum Pidana dalam Perspektif Penegakan Hukum di Indonesia".on Suseno dan Nella Sumika Putri (ed). (2013). Hukum Pidana Indonesia Perkembangan dan Pembaharuan. Bandung: Remaja Rosdakarya, p.168.

6 Pemerintah Malaysia (2007). Federal Constitution, as amendment at 27 December 2007. http://www.agc.gov.my/agcportal/uploads/files/Publications/FC/Federal\%20Consti\%20(BI\%20text).pdf . [Accessed May 10, 2017]. Pada bagian Protection against retrospective criminal laws and repeated trials, Article 7 dari Federal Constitution Malaysia menyebutkan bahwa (1) No person shall be punished for an act or omission which was not punishable by law when it was done or made, and no person shall suffer greater punishment for an offence than was prescribed by law at the time it was committed. (2) A person who has been acquitted or convicted of an offence shall not be tried again for the same offence except where the conviction or acquittal has been quashed and a retrial ordered by a court superior to that by which he was acquitted or convicted.
} 
menjadikan dunia tanpa batas, sehingga hukum pun bergerak. Sulistyowati Irianto mengatakan bahwa hukum itu bergerak sesuai dengan arus perkembangan termasuk arus globalisasi. 7 Sehubungan dengan latar belakang tersebut, permasalahan yang diangkat dalam paper ini adalah bagaimanakah pengaturan kekerasan seksual atau perkosaan dalam KUHP Indonesia dan Malaysia berikut sanksi pidananya.

\section{Metode}

Kajian ini bersifat normatif dalam bentuk perbandingan hukum, dimana penulis berupaya membandingkan rumusan perbuatan perkosaan atau kekerasaan seksual dalam KUHP Indonesia dengan KUHP Malaysia. Data yang dikaji adalah data sekunder yang meliputi: (1) KUHP Indonesia yang keberlakuannya disahkan dengan UU No. 1 Tahun 1946 tentang Peraturan Hukum Pidana; dan (2) KUHP Malaysia (Act 574, Penal Code as at 1 January 2015). Penulis terlebih dahulu melakukan identifikasi pasal-pasal yang mengatur tentang perkosaan/kekerasaan seksual baik di KUHP Indonesia maupun KUHP Malaysia. Selanjutnya penulis melakukan identifikasi perbuatan-perbuatan yang termasuk ketegori perkosaan berikut sanksi pidananya. Data dari kedua KUHP tersebut kemudian diperbandingkan untuk dicari persamaan maupun perbedaannya.

\section{Hasil dan Analisis}

\subsection{Pembaharuan Hukum Pidana dan Konsep Perkosaan}

Hukum pidana merupakan sebuah sistem, yaitu sistem hukum pidana. Barda Nawawi Arief menyebutnya dengan istilah sistem pemidanaan. Istilah ini memiliki dua pengertian, dalam arti luas dan dalam arti sempit. Dalam arti luas (dalam arti fungsional) sistem pemidanaan adalah keseluruhan aturan perundang-undangan untuk operasionalisasi pidana, yakni mengatur bagaimana hukum pidana dioperasionalkan dan ditegakkan secara konkrit sehingga seseorang dapat dijatuhi pidana. Sistem pemidanaan yang demikian ini meliputi hukum pidana materiil, hukum pidana formil dan hukum pelaksanaan pidana. Sedangkan dalam arti sempit, sistem pemidanaan adalah norma-norma hukum pidana substantif, yaitu keseluruhan sistem aturan/norma hukum pidana meteriil untuk pemidanaan, atau keseluruhan sistem aturan hukum pidana untuk penjatuhan dan pelaksanaan pidana. ${ }^{8}$ Fungsionalisasi hukum pidana dalam arti sempit ini meliputi ketentuan umum (general provisions) dan ketentuan khusus (specific provisions). Ketentuan umum dari hukum pidana substantif diatur dalam buku I KUHP (Pasal 1-103), sedangkan ketentuan khusus ada dalam buku II dan III KUHP serta peraturan-peraturan pidana di luar KUHP.

Pembaharuan hukum pidana (penal reform) dalam pengertian yang sempit berarti pembaharuan hukum pidana substantif/hukum pidana materiil atau yang biasa

\footnotetext{
${ }^{7}$ Irianto, S. Pluralisme Hukum dalam Perspektif Global, dalam Sulistyowati Irianto (ed), (2009). Hukum yang Bergerak :Tinjauan Antropologi Hukum, Jakarta: Yayasan Obor Indonesia, hal. 29.

${ }^{8}$ Arief, B.N. (2015). Perkembangan Sistem Pemidanaan di Indonesia. Semarang: Pustaka Magister, hal.1-3.
} 
disebut dengan hukum pidana. Oleh karena itu ruang lingkup pembaharuannya harus pula meliputi ketentuan umum dan ketentuan khusus. Ruang lingkup hukum pidana substantif meliputi: (1) asas dan tujuan pemidanaan; (2) aturan/pedoman pemidanaan; dan (3) masalah pokok hukum pidana yaitu tindak pidana (criminal offense), kesalahan/pertanggungjawaban pidana (criminal liability) dan pidana (criminal punishment).

Paper ini tidak mengkaji semua unsur dari pembaharuan hukum pidana seperti diungkapkan di atas untuk diperbandingakan, namun dibatasi pada unsur perbuatan dalam arti rumusan perbuatan antara dua KUHP tersebut. Rumusan perbuatan itu pun tidak semua rumusan perbuatan dalam KUHP dua negara itu (Malaysia dan Indonesia), hanya menekankan pada kekekerasan seksual yang disebut dengan perkosaan. Oleh karena itu sebelum melakukan perbandingan, penulis akan memaparkan secara berurutan konsep atau pengertian perbuatan pidana/tindak pidana dan juga konsep kekerasaan seksual atau perkosaan.

Para pakar hukum pidana menyebut perbuatan yang dapat dikenai pidana dengan berbagai macam istilah seperti tindak pidana, perbuatan pidana, peristiwa pidana, dan delik. Pengertian dari tindak pidana/delik itu pun juga bervariasi. Namun pada dasarnya suatu perbuatan itu disebut sebagai tindak pidana/delik apabila perbuatan tersebut: (1) memenuhi rumusan undang-undang; (2) bersifat melawan hukum; (3) adanya sanksi pidana; dan (4) tidak adanya alasan penghapus pidana dalam bentuk alasan pembenar. Sehubungan poin kedua yaitu sifat melawan hukum, dalam hukum pidana dikenal dua ajaran sifat melawan hukum, yaitu sifat melawan hukum formil dan materiil. Eddy O.S. Hiariej menjelaskan bahwa ajaran sifat melawan hukum formil adalah ajaran yang menyatakan suatu perbuatan itu dapat dipidana jika telah memenuhi rumusan undang-undang, artinya semua unsur-unsur dari delik itu telah dipenuhi. Sedangkan ajaran sifat melawan hukum yang materiil mempunyai dua pengertian. Pertama, sifat melawan hukum materiil dilihat dari sisi perbuatannya, yaitu perbuatan yang melanggar atau membahayakan kepentingan hukum yang hendak dilindungi oleh pembentuk undang-undang dalam rumusan delik tertentu. Sifat melawan hukum yang demikian ini melekat pada delik-delik yang dirumuskan secara materiil. Kedua, pengertian sifat melawan hukum dilihat dari sumber hukumnya yaitu mengandung makna bertentangan dengan hukum tidak tertulis atau hukum yang hidup dalam masyarakat, serta nilai-nilai keadilan dalam kehidupan sosial masyarakat. Berdasarkan fungsinya sifat melawan hukum materiil dibagi dalam fungsinya negatif dan fungsinya yang positif. Sifat melawan hukum materiil dalam fungsinya yang negatif yaitu perbuatan yang memenuhi rumusan undang-undang, tetapi karena suatu hal di luar undang-undang atau tidak bertentangan dengan rasa keadilan masyarakat maka perbuatan tersebut tidak dipidana. Sifat melawan hukum materiil dalam fungsinya yang positif mengandung arti bahwa meskipun perbuatan tersebut tidak diatur dalam peraturan perundang-undangan, namun jika perbuatan tersebut tidak sesuai dengan rasa keadilan atau norma-norma kehidupan sosial dalam masyarakat, maka perbuatan tersebut dapat dipidana. ${ }^{9}$

Perkosaan dalam Kamus Besar Bahasa Indonesia berasal dari kata dasar perkosa, artinya memaksa dengan kekerasan atau menggagahi, sehingga perkosaan artinya

\footnotetext{
9 Hiariej, E.O. (2016). Prinsip -prinsip Hukum Pidana. Yogyakarta: Cahaya Atma Pustaka. hlm. 241 243.
} 
pelanggaran dengan kekerasan. ${ }^{10}$ Istilah dalam bahasa Inggris untuk perkosaan adalah rape. Black Law Dictionary menjelaskan bahwa perkosaan (rape) adalah: (1) hubungan seksual yang melanggar hukum yang dilakukan oleh seorang laki-laki dengan seorang perempuan yang bukan isterinya dengan paksaan dan bertentangan dengan kehendak perempuan (unlawful sexual intercourse committed by a man with a woman not his wife through force and against her will); atau (2) perbuatan seksual yang melanggar hukum dengan seorang perempuan tanpa persetujuannya dengan paksaan atau ancaman kekerasan [unlawful sexual activity (especially intercourse) with a person (usually a female) without consent and usually by force or threat of injury].11 Pendek kata, berdasarkan konsep tersebut, perkosaan adalah hubungan seksual yang melanggar hukum, karena dilakukan tidak dengan persetujuan atau dengan paksaan. Nur Aina Abdulah dan Sayed Sikandar Shah Haneef, menyatakan bahwa "rape is defined as an unlawful sexual intercourse between a man and a woman without the latter's consent and against her will", (perkosaan didefinisikan sebagai sebuah hubungan seksual yang melanggar hukum antara seorang pria dan seorang wanita tanpa persetujuan si wanita dan melawan kehendaknya. 12

Konsep kekerasaan seksual sebagaimana dirumuskan dalam Declaration on the Elimination of Violence against Women memiliki ciri-ciri: (1) perbuatan itu ditujukan kepada perempuan, sehingga korbannya perempuan; (2) menyerang hak-hak perempuan; (3) menimbulkan kerugian baik itu kerugian fisik, psikis dan/atau seksual. Meskipun hanya berlaku dalam lingkup rumah tangga, UU PKDRT bisa menjadi rujukan dalam memahami konsep kekerasan seksual. Sebagaimana disebutkan dalam Pasal 8, kekerasan seksual adalah pemaksaan hubungan seksual yang dilakukan terhadap orang yang menetap dalam rumah tangga. Jadi, pada hakikatnya "pemaksaan" merupakan unsur yang harus ada dalam perbuatan kekerasan seksual, meskipun itu antara suami dan isteri.

Dengan demikian perkosaan atau kekerasan seksual adalah perbuatan seksual yang melanggar hukum karena melawan kehendak perempuan dan/atau karena persetujuan yang diperoleh karena adanya paksaan. Oleh karena itu unsur paksaan merupakan ciri spesifik dari perbuatan kekerasaan seksual atau perkosaan.

\subsection{Kekerasan Seksual/Perkosaan dalam KUHP Malaysia dan Indonesia.}

KUHP Malaysia mengatur perkosaan (rape) dalam dua pasal yaitu Pasal 375 mengatur tentang perbuatannya dan Pasal 376 mengatur tentang sanksi pidana terhadap perbuatan perkosaan itu. Adapun pasal-pasal itu sebagai berikut: ${ }^{13}$

Section 375

10 Departemen Pendidikan dan Kebudayaan. (1998). Kamus Besar Bahasa Indonesia, Jakarta: Balai Pustaka, hlm. 757.

${ }^{11}$ Graner, B.A. (ed). (2004). Black Law Dictionary, Paul Mint: West Publishing, hlm. 3952.

12 Abdullah, N.A. dan Haneef, S.I.S (2017). "The Statury Rape Law In Malaysia: An Analysis From Shariah Perspective". International Journal of Business Economics and Law, (14):5:9 13.

13 Malaysia Government. (2018). Act 574 Penal Code as at 1 February 2018, http://www.agc.gov.my/agcportal/uploads/files/Publications/LOM/EN/Penal\%20Code\%20ACT\%20574 \%20-\%20TP\%20LULUS\%2021_2_2018.pdf [Accessed March 5, 2018]. 
A man is said to commit "rape" who, except in the case hereinafter excepted, has sexual intercourse with a woman under circumstances falling under any of the following descriptions:

a) against her will;

b) without her consent;

c) with her consent, when her consent has been obtained by putting her in fear of death or hurt to herself or any other person, or obtained under a misconception of fact and the man knows or has reason to believe that the consent was given in consequence of such misconception;

d) with her consent, when the man knows that he is not her husband, and her consent is given because she believes that he is another man to whom she is or believes herself to be lawfully married or to whom she would consent;

e) with her consent, when, at the time of giving such consent, she is unable to understand the nature and consequences of that to which she gives consent;

f) with her consent, when the consent is obtained by using his position of authority over her or because of professional relationship or other relationship of trust in relation to her;

g) with or without her consent, when she is under sixteen years of age.

Section 376:

1) Subject to subsections (2), (3) and (4), whoever commits rape shall be punished with imprisonment for a term which may extend to twenty years, and shall also be liable to whipping.

2) Whoever commits rape on a woman under any of the following circumstances:

a) at the time of, or immediately before or after the commission of the offence, causes hurt to her or to any other person;

b) at the time of, or immediately before or after the commission of the offence, puts her in fear of death or hurt to herself or any other person;

c) the offence was committed in the company of or in the presence of any other person;

d) without her consent, when she is under sixteen years of age;

e) with or without her consent, when she is under twelve years of age;

f) with her consent, when the consent is obtained by using his position of authority over her or because of professional relationship or other relationship of trust in relation to her;

g) at the time of the offence the woman was pregnant;

h) when by reason or on occasion of the rape, the woman becomes insane;

i) when he knows that he is afflicted with the Human Immuno-Deficiency Virus (HIV)/Acquired Immune Deficiency Syndrome (AIDS) or any other sexually transmissible disease and the virus or disease is or may be transmitted to the woman;

j) when by reason or on occasion of the rape, the woman commits suicide; or 
k) when he knew of the mental disability, emotional disorder or physical handicap of the woman at the time of the commission of the crime,

shall be punished with imprisonment for a term of not less than ten years and not more than thirty years and shall also be liable to be whipping

3) Whoever commits rape on a woman whose relationship to him is such that he is not permitted under the law, religion, custom or usage, to marry her, shall be punished with imprisonment for a term of not less than eight years and not more than thirty years, and shall also be punished with hipping of not less than ten strokes.

4) Whoever whilst committing or attempting to commit rape causes the death of the woman on whom the rape is committed or attempted shall be punished with death or imprisonment for a term of not less than fifteen years and not more than thirty years, and shall also be punished with whipping of not less then ten strokes.

Berdasarkan substansi Pasal 375 KUH Pidana, diketahui ada beberapa bentuk perbuatan yang disebut sebagai perkosaan dan dapat dijatuhi pidana. Perbuatanperbuatan tersebut adalah: (1) hubungan seksual yang melawan kehendak perempuan; (2) hubungan seksual tanpa persetujuan perempuan; (3) hubungan seksual dengan persetujuan perempuan karena ancaman atau kesalahpamahan; (4) hubungan seksual dengan persetujuan perempuan karena perempuan percaya bahwa laki-laki akan menikahinya; (5) hubungan seksual dengan persetujuan perempuan, karena perempuan tidak memahami konsekwensi dari persetujuannya; (6) hubungan seksual dengan persetujuan perempuan, yang persetujuan itu diperoleh karena adanya hubungan kekuasaan, profesi atau kepercayaan lain; (7) hubungan seksual dengan persetujuan atau tanpa persetujuan perempuan yang berusia di bawah 16 tahun.

Konsep perkosaan (rape) dalam KUHP Malaysia ini lebih ketat, karena di Malaysia penetrasi vagina oleh penis, bagaimanapun ringannya cukup memadai untuk dikategorikan sebagai hubungan seksual yang memenuhi kriteria perkosaan. Terkait hal ini, Kasinathan Nadesan menyatakan: ${ }^{14}$

"In Malaysia, vaginal penetration by the penis, however slight, is sufficient to constitute sexual intercourse for the offence of rape. Even the tip of the penis between the labia has been accepted as intercourse in law. If penetration cannot be satisfactorily proved, the defendant may be convicted of attempted rape and if intent is not proved, he may be convicted of indecent assult. It is not necessary to prove the completion of sexual intercourse by orgasm or ejaculation of semen."

Hal ini berbeda dengan konsep perkosaan yang ada dalam KUHP Indonesia dan negara lain (seperti Belanda, German, Singapura atau yang lain). ${ }^{15}$ KUHP di negara-

\footnotetext{
${ }_{15}^{14}$ Nadesan, K. (2002). “Rape-The Malaysia Scenario". Malaysian Journal Pathol, 24(1): 9-14.

15 Di Belanda tindak pidana perkosaan diatur dalam Section 242, Criminal Code of Netherland, http://www.legislationonline.org/documents/section/criminal.codes. [Accessed May10, 2017]. Section 242: Any person who by an act of violence or any other act or by threat of violence or threat of any other act compels a person to submit to acts comprising or including sexual penetration of the body shall be guilty of rape and shall be liable to a term of imprisonment not exceeding twelve years or a fine of the fifth category. Di Jerman, tindak pidana perkosaan diatur dalam Pasal 177 German Criminal Code. http://www.legislationonline.org/documents/section/criminal.codes. [Accessed May 10, 2017]. Section 177 (1) Whosoever coerces another person: 1. by force; 2. by threat of imminent danger to life or limb; or 3. by exploiting a situation in which the victim is unprotected and at the mercy of the offender, to suffer sexual acts by the offender or a third person on their own person or to engage actively in sexual activity with the offender or a third person, shall be liable to imprisonment of not less
} 
negara itu merumuskan perkosaan bisa dikatakan sama dengan konsep perkosaan dalam Black Law Dictionary, bahwa hubungan seksual dengan persetujuan bukan perkosaan, meskipun persetujuan diberikan dengan terpaksa. KUHP Malaysia berbeda, sebagaimana dapat dilihat dalam rumusan Pasal 375 huruf (c), (d), (e), dan (f). Jadi rumusan perkosaan di KUHP Malaysia lebih terperinci.

Secara garis besar, perkosaan di Malaysia dari sisi perbuatan pelaku dapat dibedakan menjadi dua yaitu perkosan dengan persetujuan dan perkosaan tanpa persetujuan atau perkosaan yang melawan kehendak perempuan. Selain itu, dari sisi korban, perkosaan dapat dibedakan: (1) perkosaan yang ditujukan kepada perempuan secara umum; (2) perkosaan yang ditujukan kepada perempuan yang mempunyai hubungan tertentu (hubungan profesi, kerja atau hubungan kepercayaan yang lain); dan (3) perkosaan yang ditujukan kepada anak perempuan.

Di Indonesia, konsep perkosaan dirumuskan dalam Pasal 285 KUHP yang menyatakan: "Barang siapa dengan kekerasan atau ancaman kekerasan memaksa seorang wanita bersetubuh dengan dia di luar perkawinan, diancam karena melakukan perkosaan dengan pidana penjara paling lama dua belas tahun."

Rumusan itu menunjukkan bahwa hubungan seksual (persetubuhan) dikatakan sebagai perkosaan apabila perbuatan dimaksud dilakukan dengan kekerasan atau ancaman kekerasan sebagai sarana untuk memaksa si wanita. Jadi unsur kekerasan atau ancaman kekerasan harus ada. Tanpa adanya paksaan dengan kekerasaan atau ancaman, tidak bisa dikatakan sebagai perkosaan. Dengan demikian, Pasal 285 tidak dapat diterapkan apabila persetubuhan itu dilakukan secara suka rela, atau berdasarkan kesepakatan baik secara langsung atau tidak langsung.

Rumusan yang demikian itu sama dengan rumusan pasal-pasal perkosaan di beberapa negara yang dicontohkan di atas, khususnya German dan Belanda. Hal ini dapat dipahami mengingat KUHP Indonesia merupakan turunan dari Wetboek van Strafrecht (W.v.S) pada masa kolonial yang kemudian telah mengalami berbagai penyesuaian berdasarkan UU No. 1 Tahun 1946 tentang Peraturan Hukum Pidana.

Konsep KUHP tentang perkosaan ini sesuai dengan konsep kekerasan terhadap perempuan seperti yang tercantum dalam Declaration on the Elimination of Violence against Women, bahwa unsur kekerasan atau ancaman kekerasan untuk memaksa ini merupakan penyerangan terhadap hak-hak perempuan dalam hal hak reproduksinya, yang berakibat pada kerugian seksual, namun juga bisa berakibat pada kerugian psikhis (trauma). Selain Pasal 285, ketentuan lain yang mengatur tentang perkosaan adalah Pasal 286 (korban dalam keadaan tidak berdaya atau pingsan) dan Pasal 287 (korban belum 15 tahun atau umurnya tidak jelas).

Membandingkan dua model pengaturan tentang kekerasan seksual di atas, kita bisa melihat bahwa formulasi perbuatan yang berhubungan dengan hak-hak perempuan di KUHP Malaysia lebih luas dari KUHP Indonesia. Hal demikian juga dijumpai dalam

than one year. Di Singapura tindak pidana ini diatur dalam Pasal 375 Penal Code of Singapore. http://www.legislationonline.org/documents/section/criminal.codes. [Accessed Mayv10, 2017]. Section 375 - - (1) Any man who penetrates the vagina of a woman with his penis — (a) without her consent; or (b) with or without her consent, when she is under 14 years of age,

shall be guilty of an offence 
perumusan tentang kekerasan dalam rumah tangga (domestic violence), yang ternyata juga lebih terperinci. ${ }^{16}$

Sanksi pidana terhadap bentuk-bentuk hubungan seksual yang disebut perkosaan di Malaysia sebagaimana diatur Pasal 375 KUHP Malaysia berupa pidana penjara dan dera yang dirumuskan secara kumulatif. Hal ini ditunjukkan dengan penggunaan kata sambung "dan" ("and"). Hukuman dera ini sebenarnya merupakan hukuman yang berasal dari hukum Islam untuk perbuatan zina (adultery), seperti Firman Allah dalam Al Quran Surat An Nur (24) ayat 2 yang artinya: "Perempuan yang berzina dan lakilaki yang berzina, maka deralah tiap-tiap seorang dari keduanya seratus kali dera, dan janganlah belas kasihan kepada keduanya mencegah kamu untuk (menjalankan) agama Allah, jika kamu beriman kepada Allah, dan hari akhirat, dan hendaklah (pelaksanaan) hukuman mereka disaksikan oleh sekumpulan dari orang-orang yang beriman."

Perkosaan berbeda dengan zina, karena dalam perkosaan ada unsur pemaksaan dari pelaku (laki-laki), sehingga bagi perempuan (korban) menurut hadist tidak mendapatkan sanksi, hanya pihak laki-laki (pelaku) mendapatkan sanksi. Perkosaan pernah terjadi di masa Rasulullah. Menurut sebuah hadist riwayat At-Tirmidziy, dalam kasus tersebut Rasulullah menjatuhkan hukuman rajam kepada laki-laki (pelaku) dan membebaskan perempuan dari hukuman hudud. ${ }^{17}$

Pengakuan Islam sebagai agama negara di dalam Konstitusi Malaysia berdampak pada kehidupan hukum termasuk hukum pidananya. Oleh karena itu wajar apabila sanksi pidana dalam kasus perkosaan mengakomodasi model hukuman yang dikenal dalam hukum Islam. Sebagaimana telah disebutkan, sanksi pidana terhadap perbuatan perkosaan dalam KUHP Malaysia adalah pidana penjara yang kumulatif dengan sanksi dera. Hanya saja terkait sanksi dera, tidak diatur di dalam KUHP tersebut berapa kali dera yang harus dijatuhkan.

Seperti dijelaskan oleh Farid Sufian Shuaib, hukum Islam sudah tumbuh dan berkembang secara evolusioner sejak Malaysia merdeka, karena konstitusi memberikan akses untuk menerapkan hukum Islam. Hal ini berlaku baik di tingkat negara bagian (state) maupun di tingkat Persekutuan (Federation) untuk menetapkan perbuatan-perbuatan yang bertentangan dengan Islam sebagai pelanggaran dan dijatuhi hukuman. ${ }^{18}$

Di Indonesia, sanksi terhadap perbuatan perkosaan sebagaimana diatur dalam Pasal 285 KUHP adalah sanksi tunggal berupa pidana penjara dengan waktu paling lama dua belas (12) tahun. Meskipun mayoritas penduduk Indonesia beragama Islam, namun Islam bukan agama resmi negara seperti halnya Malaysia. Konsep yang dianut di Indonesia adalah kepercayaan pada Tuhan Yang Maha Esa. Oleh karena itu hukum Islam tidak diakomodasi secara apa adanya ke dalam peraturan perundang-undangan, melainkan pengakomodasian spirit (nilai- nilai) yang terkandung di dalamnya.

\footnotetext{
${ }^{16}$ Kuswardani. (2017). "Bentuk-bentuk Kekerasan Domestik \& Permasalahannya”. Jurnal Hukum dan Pembangunan. 47(4):421-438.

${ }^{17}$ Lidwa Pustaka.(2014). Kitab Hadist Sembilan Imam, http://wwlidwa.pustaka.com, [accessed May 8, 2016]

${ }^{18}$ Shuaib, F.S.(2012). “The Islamic Legal System In Malaysia”. Pacific Rim Law \& Policy Journal , 21(1):85-113.
} 
KUHP yang saat ini sedang dalam proses pembaharuan, seharusnya melihat perkembangan konsep kejahatan secara global dan memperhatikan formulasi KUHP negara lain sebagai bahan pembanding dalam melakukan pembaharuan. Hal ini mengingat pembaharuan KUHP merupakan reorientasi dan reformasi hukum pidana yang sesuai dengan nilai sentral bangsa Indonesia baik nilai sosial-politik, sosialfilosofis, maupun sosial-budaya. Oleh karena itu dalam melakukan pembaharuan hukum pidana harus dilakukan dengan dua pendekatan yaitu pendekatan kebijakan dan pendekatan nilai. ${ }^{19}$

Selanjutnya sebagaimana dijelaskan oleh Barda Nawawi Arief, pendekatakan kebijakan itu mencakup tiga aspek, yaitu: (1) bahwa pembaharuan hukum pidana itu sebagai upaya untuk menanggulangi masalah-masalah sosial, termasuk masalahmasalah kemanusiaan; (2) bahwa pembaharuan hukum pidana pada hakikatnya merupakan upaya perlindungan masyarakat dalam rangka upaya penanggulangan kejahatan; dan (3) bahwa pembaharuan hukum pidana merupakan upaya memperbaharui substansi hukum dalam rangka mengefektifkan penegakan hukum (pidana). ${ }^{20}$

Berdasarkan pendekatan kebijakan khususnya terkait aspek ketiga, pembaharuan hukum pidana diwujudkan melalui mekanisme kriminalisasi dan dekriminalisasi. Oleh karena itu, rumusan pasal perkosaan dalam KUHP perlu ditinjau ulang dengan memperhatikan perkembangan rumusan dalam KUHP negara lain, seperti Malaysia.

Pendekatan nilai baik dalam aspek sosial-politik, sosial-filosofis dan sosial-budaya harus berorientasi pada Pancasila yang merupakan cita hukum bangsa Indonesia. Nilai-nilai Pancasila adalah nilai-nilai yang lahir dari jiwa bangsa Indonesia dan merupakan spirit yang harus dicerminkan dalam setiap peraturan hukum, khususnya undang-undang pidana/KUHP. Sehubungan dengan itu, sebenarnya persetubuhan di luar nikah sangat dikutuk oleh masyarakat dan dianggap sebagai aib keluarga. Di Bali misalnya, hukum adat melarang hubungan yang demikian dan perbuatan demikian termasuk delik adat. ${ }^{21}$ Hal yang sama berlaku pula di dalam masyarakat Bugis, Makasar. Perbuatan persetubuhan di luar nikah dilarang dan merupakan delik adat yang disebut dengan malaweng. 22

Nilai-nilai yang hidup dalam masyarakat sebagaimana dua contoh di atas adalah nilai yang bersifat spiritual, karena persetubuhan di luar nikah adalah perbuatan terlarang menut ajaran Tuhan/agama (Islam), apalagi jika dilakukan dengan unsur tipu daya dan paksaan. Hal demikian jelas bertentangan atau tidak sesuai dengan nilai-nilai spiritual.

Fenomena kekerasan seksual yang terjadi di masyarakat semakin memprihatinkan. Sebagaimana ditunjukkan dalam catatan akhir tahun KOMNAS Perempuan, kekerasan

${ }^{19}$ Arief, B.N. (1996). Bunga Rampai Kebijakan Hukum Pidana, Bandung: Citra Aditya Bakti, hlm. 32.

${ }^{20}$ Ibid. hlm. 33.

${ }^{21}$ Jaya, N.S.P. (2001). Disertasi: Relevansi Hukum Pidana Adat dalam Pembaharuan Hukum Pidana Nasional. Jakarta: Pendidikan Pascasarjana, Program Doktor, Universitas Indonesia. hlm. 198.

${ }^{22}$ Ubee, A. (2008). Hukum Pidana Adat Kesusilaan Malaweng: Kesinambungan dan Perubahannya, Jakarta: Yarsif Watampone, hlm. 140. 
seksual yang dilakukan oleh pacar menduduki peringkat yang paling tinggi, sehingga perlu upaya-upaya penanggulangan yang lebih efektif. Salah satu upaya yang mendesak untuk dilakukan adalah pendayagunaan hukum pidana melalui penal reform.

\section{Kesimpulan}

Formulasi perkosaan dalam KUHP Malaysia mengakomodasi nilai-nilai ajaran Islam, baik dari sisi perbuatan maupun dari sisi sanksi pidananya dan rumusannya lebih luas dibanding KUHP Indonesia. Dalam KUHP Malaysia, perbuatan perkosaan atau kekerasaan seksual tidak hanya dilakukan dengan kekerasan, atau ancaman kekerasaan, atau melawan kehendak perempuan, atau tanpa kesepakatan perempuan, tetapi bisa juga perbutan itu dilakukan dengan kesepakatan perempuan, yang kesepakatan itu diperoleh karena sebab-sebab tertentu, misalnya karena adanya hubungan atasan-bawahan. Sanksi pidana terhadap perbuatan kekerasan seksual/perkosaan di Malaysia tidak hanya berupa pidana penjara, tetapi juga hukuman dera/cambuk, yang bersifat kumulatif.

Dalam KUHP Indonesia, hubungan seksual dianggap sebagai perkosaan apabila dilakukan dengan kekerasan, atau ancaman kekerasaan. KUHP tidak menjelaskan secara terperinci, sebagaimana KUHP Malaysia. Oleh karena itu hubungan seksual antara seorang laki-laki dengan seorang perempuan yang dilakukan dengan kesepakatan tidak bisa dipidana karena tidak adanya unsur kekerasaan atau ancaman kekerasan.

Reformulasi terhadap perkosaan perlu dilakukan dengan melihat fakta-fakta yang terjadi, mengingat hukum pidana sampai saat ini masih dianggap sebagai obat dalam penanggulangan kejahatan. Selain itu, dengan reformulasi ini aparat penegak hukum dalam melaksanakan tugas kewajibanya mempunyai panduan yang jelas untuk memproses suatu perkara yang demikian itu jika terjadi di wilayahnya.

\section{References}

\section{Buku:}

Arief, B.N. (1996). Bunga Rampai Kebijakan Hukum Pidana. Bandung: Citra Adtya Bakti. - (2015). Perkembangan Sistem Pemidanaan di Indonesia. Semarang: Pustaka Magister.

Departemen Pendidikan dan Kebudayaan. (1998). Kamus Besar Bahasa Indonesia. Jakarta: Balai Pustaka.

Duff, R.A. et.al. (ed). (2014). Criminalization: The Political Morality of the Criminal Law. USA: Oxford University Press.

Garner, B.A. (ed). (2004). Black Law Dictionary. Paul Mint: West Publishing.

Hiariej, E.O. (2016). Prinsip-prinsip Hukum Pidana. Yogyakarta: Cahaya Atma Pustaka.

Ibrahim, J. (2006). Teori dan Metode Penelitian Hukum Normatif. Malang: Banyumedia Publishing.

Irianto, S. (ed). (2009). Hukum yang Bergerak: Tinjauan Antropologi Hukum. Jakarta: Yayasan Obor Indonesia.

Jaya, N.S.P. (2001). Disertasi: Relevansi Hukum Pidana Adat dalam Pembaharuan Hukum Pidana Nasional, Jakarta: Pendidikan Pascasarjana, Program Doktor, Universitas Indonesia. 
Lamintang, P.A.F. (2013), Dasar-dasar Hukum Pidana Indonesia. Bandung: Citra Adtiya Bakti.

Suseno dan Putri, N.S. (ed). (2013). Hukum Pidana Indonesia dan Pembaharuan. Bandung: Remaja Rosdakarya.

Ubee, A. (2008). Hukum Pidana Adat Kesusilaan Malaweng: Kesiambungan dan Perubahannya. Jakarta: Yarsif Watampone.

Artikel Jurnal:

Abdullah, N.A. dan Haneef, S.I.S. (2017). "The Statutory Rape Law in Malaysia: An Analysis from Shariah Perspective". International Journal of Business Economics and Law, (14)5. doi: http://ijbel.com/wpcontent/uploads/2017/12/KLIisc5_11.pdf

Kuswardani. (2017). “Bentuk-bentuk Kekerasan Domestik \& Permasalahannya”. Jurnal Hukum dan Pembangunan. 47(4). doi: http://dx.doi.org/10.21143/jhp.vol47.no4.1592.

Nadesan, K. (2002). "Rape-The Malaysia Scenario". Malaysian Journal Pathol, 24(1), doi: http://mjpath.org.my/past_issue/MJP2002.1/rape-the-Malaysianscenario.pdf

Shuaib, F.S. (2012). “The Islamic Legal System In Malaysia”. Pacific Rim Law \& Policy Journal, 21(1). doi: http://hdl.handle.net/1773.1/1094

Internet:

KOMNAS Perempuan. (2017). Catatan Tahunan (CATAHU) 2017. Online from https://www.komnasperempuan.go.id/file/pdfffile/2017\% 20Siaran \% 20Pers/Lembar\% 20Fakta\%20Catahu\%202017.pdf. [Accessed May 10, 2017].

Legislationle. (2013). Criminal Code. online from http://www.legislationonline.org/documents/section/criminal.codes. [Accessed 10 Mei 2017].

Legislationonline.(2012). Criminal Code of Netherland,online from http://www.legislationonline.org/documents/section/criminal.codes. [Accessed 10 Mei 2017].

Lidwa Pustaka. (2014). Kitab Hadist Sembilan Imam, online from http:/ / wwlidwa.pustaka.com, [accessed May 8, 2017].

Malaysia Government. (2018). Act 574 Penal Code as amendment at 1 February 2018, online from: http://www.agc.gov.my/agcportal/uploads/files/Publications/LOM/EN/Penal\% 20Cod e\%20ACT\%20574\%20-\%20TP\%20LULUS\%2021_2_2018.pdf [Accessed March $5,2018]$.

Peraturan Perundang-undangan:

Undang-undang Nomor 1 Tahun 1946 tentang Peraturan Hukum Pidana (1946). 